\title{
Progesterone and estrogen levels in Awassi ewes treated with vaginal sponges
}

\author{
A.A. Omar \\ Coll. of Vet. Med. Unive. of AL-Anbar
}

Abstract

This study was conducted on 10 healthy Iraqi Awassi ewes that examined by ultrasonography technique, with ages between 2 to 3 years, presented at the farm of the College of Veterinary Medicine, Al-Anbar University, Fallujah, during the period from the end of the February until the half of the March 2012. Vaginal sponges saturated with 40mg Flurogestone acetate were inserted in the vagina of each tested animals in order to induce estrus For synchronization for 14 days, at day 13of the experiment the animals were injected i.m. by Equine chorionic gonadotropine eCG (500 i.u.) then the sponges were removed and the animals injected i.m. with (200 i. u.) of Human chorionic gonadotropine (HCG). Blood samples were collected from jugular vein with vacutainer tubes each two days until the experiment was complete. Serum was collected after centrifugation with a speed $3000 \mathrm{R} / \mathrm{m}$ for 10 minutes. Values of estrogen and progesterone hormones in serum were estimated by Enzyme Linked Immuno Sorbent Assay (ELISA) technique. Values of the estrogen and progesterone in the treated animals were $(1.1932 \pm 0.02380),(0.9558 \pm 0.3282)$ respectively, while the levels of the two hormones for the control group was $(1.1138 \pm 0.02295)$ for the estrogen and $(0.8702 \pm 0.0152)$ for the progesterone. There was a significant different between the level of estrogen and progesterone hormones $\mathrm{P}<0.05$ in a treated group as a compare with the control group. It was concluded from this study that estrus synchronization of the ewes with vaginal sponge affected the values of estrogen and progesterone hormones in the serum.

\section{Introduction}

The success of reproduction depends on some complex physiology events, which lead to production and emission of mature gametes, and some behavioral changes that ensure ova and sperm will be in contact at appropriate time (Caraty et al., 2002). Estrus synchronization is commonly used in order to induce estrus and ovulation during the anestrous period, and to synchronize the estrus and shorten the duration of lambing, thus minimizing labour cost, during the breeding season (Wildeus, 2000; Schnederand Rehbock, 2003). There are several methods used for synchronization of oestrus, these includes the application of progesterone, prostaglandin and melatonin (Beardon et al., 2004). Synchronization and superovulation includes two stages. The first

\section{Materials and Methods}

This study was conducted on10 healthy Iraqi Awassi ewes that examined by ultrasonography technique, with ages stage showed the insertion of vaginal sponges in the vagina while the second stage includes injection of $\mathrm{HCG}$ and eCG before and after sponges withdrawal. Hormonal levels have been estimated previously during oestrus synchronization (OS). These hormones involve Estrogen, Progesterone, FSH and LH. A considerable amount of information was produced and published on estrus synchronization in sheep (Wildeus, 2000). There was a little information about hormonal levels of estrogen and progesterone during oestrus synchronization. The aim of this study was to measure the levels of progesterone and estrogen before and during treatment with vaginal sponges in Awassi ewes.

between 2 to 3 years, presented at the farm of the College of Veterinary Medicine, AlAnbar University, Fallujah, during the 


\section{$\begin{array}{llll}\text { AL-Qadisiya Journal of Vet.Med.Sci. } & \text { Vol./12 } & \text { No./1 }\end{array}$}

period from the end of the February until the half of the March 2012. Vaginal sponges saturated with $40 \mathrm{mg}$ Flurogestone acetate were inserted in the vagina of each tested animals in order to induce estrus For synchronization for 14 days, at day 13 of the experiment the animals were injected i.m. by Equine chorionic gonadotropine eCG (500 i.u.) then the sponges were removed and the animals injected i.m. with (200 i. u.) of Human chorionic gonadotropine (HCG).

\section{Results and Discution}

Mean serum progesterone concentrations $(\mathrm{ng} / \mathrm{ml})$ of ewes are shown in table -1 and figure 1,2 . The mean serum progesterone concentration during the periods of sponges' insertion was $(0.9558 \pm 0.0328) \mathrm{ng} / \mathrm{ml}$ as compared with control group. No significant differences were found between the mean of progesterone concentration in treated and control group. This result agreed with the findings of Abu Gazal (2012). This might be due to that luteolytic mechanism results in progesterone decrease to basal levels in less than one day (Menchaca and Gabriel, 1999), on the other hand increase progesterone levels as a result of eCG administration leads to improve fertility of the ewes (Kor et al.,
Blood samples were collected from jugular vein with vacutainer tubes each two days until the experiment was complete. Serum was collected after centrifugation with a speed $3000 \mathrm{R} / \mathrm{m}$ for 10 minutes. Values of estrogen and progesterone hormones in serum were estimated by Enzyme Linked Immuno Sorbent Assay (ELISA) technique. Statistical analysis was done by student t_test (Steele and Torrie, 1980).
2012; Wildeus, 2000). Mean serum estrogen concentration $(1.1932 \pm 0.0238)$ was found in a higher concentration during estrus synchronization as compared with control group. These high levels of estradiol further confirmed the presence of oestrus phase in animals (Karsch et al., 1979; Kaya et al., 2005). This might be due to the effect of eCG (equine chorionic gonadotropine) which stimulate ovarian follicular growth resulted in high estrogen level (Hafez and Hafez, 2000; pineda and Dooley; 2003).It was concluded from this study that estrus synchronization of the ewes with vaginal sponge affected the values of estrogen and progesterone hormones in Awassi ewes' serum.

Table -1-

\begin{tabular}{|l|c|c|}
\hline Gropes & Progesterone & Estrogen \\
\hline Treated & $0.9558 \pm 0.328$ & $1.1932 \pm 0.238 *$ \\
\hline Control & $0.08702 \pm 0.0105$ & $1.1138 \pm 0.0229$ \\
\hline
\end{tabular}

Showed hormones level

* There was a significant difference between different in $(\mathrm{P}<0.05)$ 


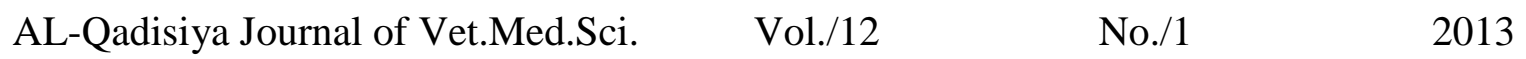

Figure -1-

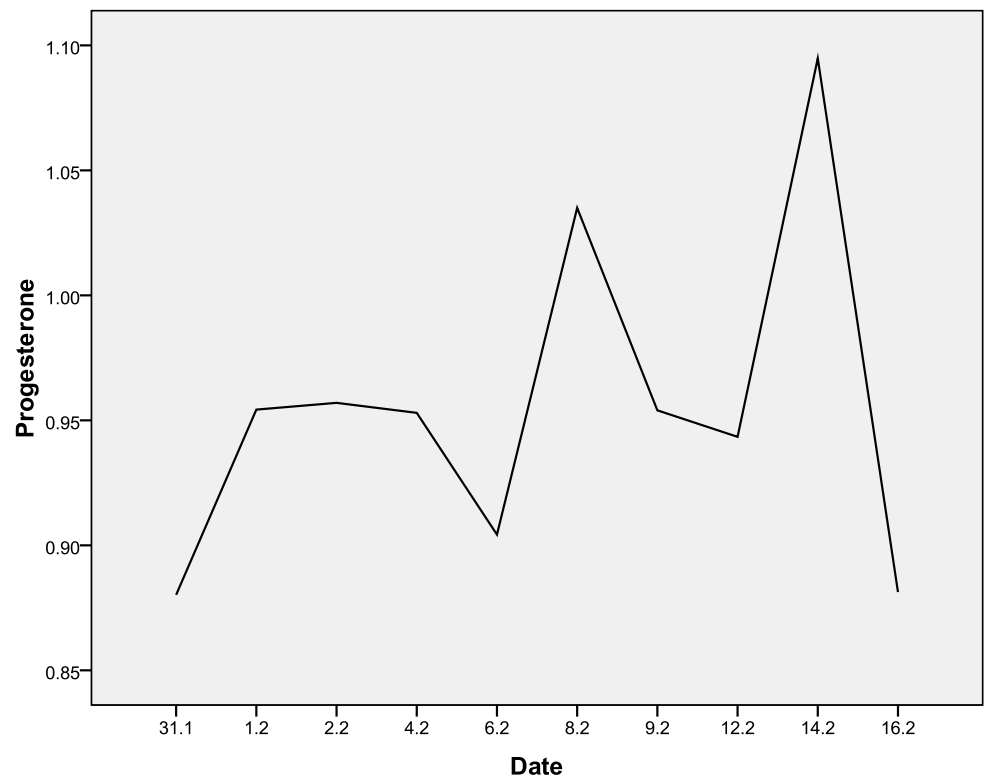

Showed the level of progesterone during different period (days).

Figure -2-

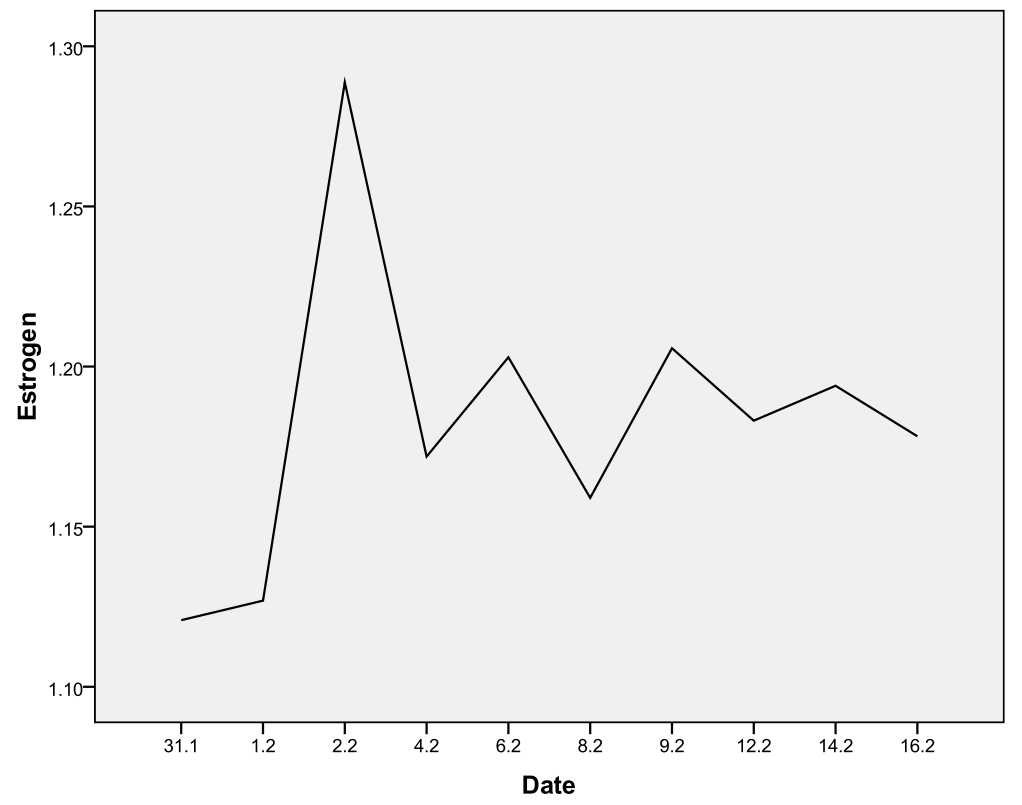

Showed the level of estrogen during different period (days).

\section{References}

1. Abu Gazal, B. M., 2010. Different Estrus

Induction protocols during the nonbreeding season in Assaf Ewes. M.S.C. Thesis, Al.Najah National university, Faculty of Graduate studies, Nablus, Palestine.

2. Bearden, H.J., Fuquay, J. W. and Willard, S.T., 2004. Applied Animal 
Reproduction $6^{\text {th }}$ ed. New Jersy. Person prentice Hall Inc. PP.247249.

3. Caraty, A., Delaleu, B., Chesneau, D. and Fabre-NYS, C., 2002. Sequential role of E2 and GnRH for the expression of oestrus behavior in ewes. Endocrinology, 143, 139-145.

4. Hafez, B. and Hafez, E. S. E. 2000. Reproduction in farm Animals, $7^{\text {th }}$ ed., Lippincott Willians and Wilkins.

5. Kirsch, F. J., Foster, D. L., Legan, S. J., Ryan, K. D. and Peter, G. K., 1979. Control of the preovulatory endocrine events in the ewe: Interrelation ship of estradiol, progesterone and luteinizing hormone. Endocrinology, 105 (2): 421-426.

6. Kaya, M., YiLdiz, S. and Guven, B., 2005. The determination of plasma progesterone, Oestradiol - 173 and LH levels during Oestrus period of Tuj ewe- lambs following Oestrus induction. Review Med.Vet., 156: (12) 628-632.
7. Schneider, F. and Rehbock. F., 2003. Induction of fertile cycles in blackhead sheep during the anoestrus period. Arch. Terz., Dummerstorf, 46: 47-61.

8. Steele RGD and Torrie, 1980.Principles of statistic, $2^{\text {nd }}$ ed. Mac- Graw Hill Book Co.

9. Kor, N.M., Sadeghi, S. and Ziaei, N., 2012. Comparison reproductive performance in Kermani ewes treated with two synchronization methods and subsequent eCG treatment out of breading season. Int. J. Biol. Med. Res., 3 (2): 14851489.

10. Menchaca, A. and Gabriel, A., 1999. Pharmacological management of the ovarian function, Encyclo. Life support Sys. PP.1-10.

11. Pineda, M. H. and Dooley, M.P., 2003. McDonald's Veterinary Endocrinology and Reproduction. $5^{\text {th }}$ ed., Iowa state press, 326-360.

12. Wildeus, S., 2000. Current concepts in synchronization of estrus: sheep and goats J. Anim. Sci., 77: 1-14.

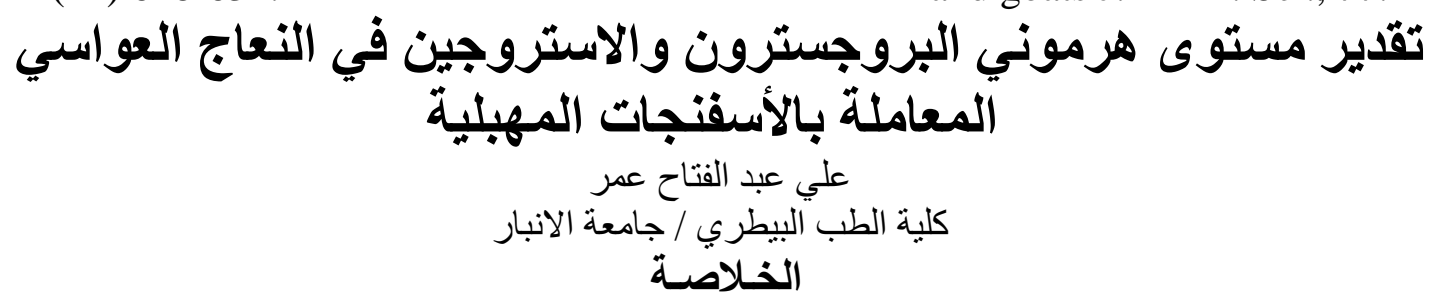

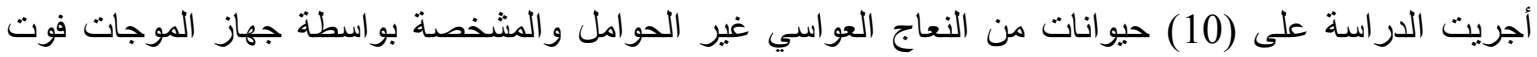

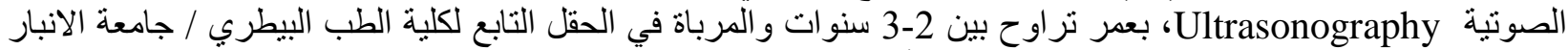

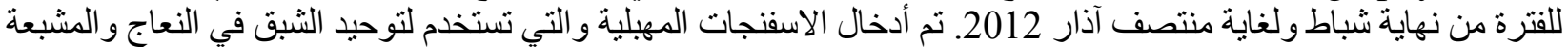

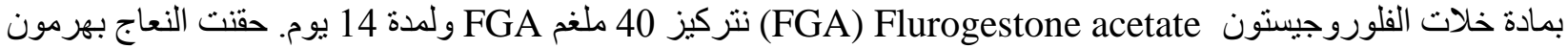

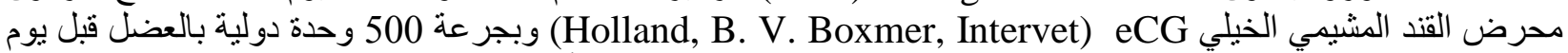

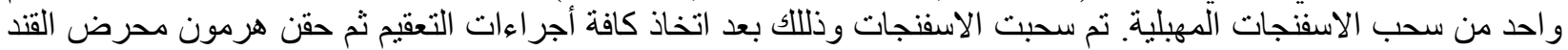

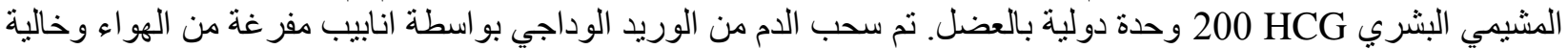

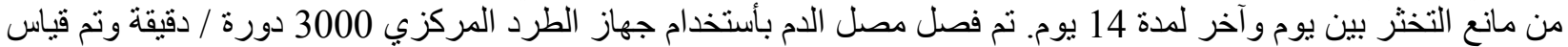

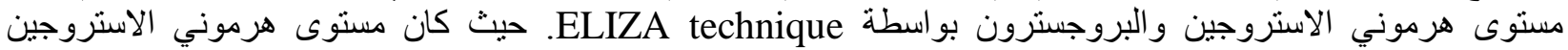

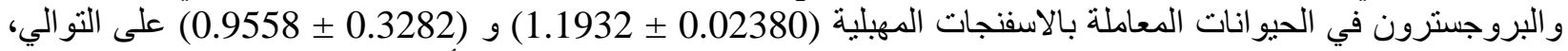

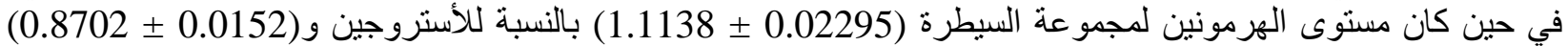

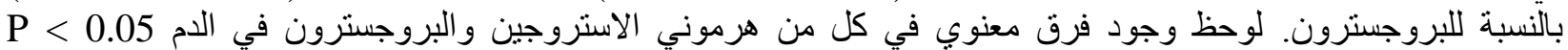

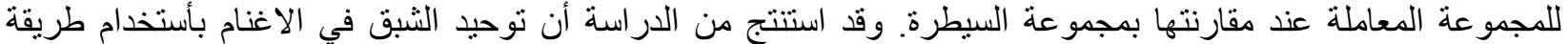
الاسفنجات المهبلية لها تأثير معنوي على مستوى هرموني الاستروجين و البروجسترون في دم النعاج. 